\title{
Dominasi Dua Citra Perempuan dan Isu Kekerasan dalam Novel Shahraz:
} Satu Kajian Feminis

\author{
R. Myrna Nur Sakinah, Ria Nirwana \\ myrnanursakinah@gmail.com, ria.nirwana2@gmail.com
}

\begin{abstract}
ABSTRAK
Penelitian ini menampilkan dua jenis citra perempuan dan isu kekerasan direpresentasi dalam novel Shahraz: The Holy Woman. The Holy Woman adalah novel yang didominasi oleh tokoh perempuan. Tokoh perempuan yang ditampilkan dalam dua novel ini didominasi melalui dua jenis citra perempuan. Novel ini menunjukkan citra perempuan yang teropresi dianggap sebagai salah satu bentuk dari tindak kekuasan patriarki. Kekuasaan patriarki yang sewenang-wenang mengakibatkan timbulnya sebuah kekerasan, baik itu secara seksual ataupun sosial budaya. Analisis untuk menunjukkan penggambaran tokoh perempuan pertama-tama dilakukan analisis berbagai citra perempuan dengan menggunakan teori yang diutarakan oleh Ferguson. Analisis citra perempuan ini berkaitan dengan isu kekerasan. Dari analisis yang dilakukan pada novel ini terlihat bahwa ada dua jenis citra perempuan yang ditampilkan dan mendominasi. Perempuan sebagai perempuan yang diidealkan dan perempuan objek seks. The Holy Woman juga menunjukkan keterkaitan kekerasan seksual dan sosial budaya yang tercermin dari citra perempuan teropresi dan teraniaya oleh struktur patriarkal.
\end{abstract}

Kata kunci: Shahraz, citra perempuan, kekerasan, dan patriarkal

\section{Images of women and violence presented in Shahraz's novels: a theory of}

\section{Feminism}

\begin{abstract}
This thesis demonstrates different images of women and violence presented in novel by Shahraz: The Holy Woman is novel that dominated by female characters. Through the analysis of the images of women, the novels show how women's oppression is a consequence of patriarchal power, which despotically result in abuse, both sexual and social. The research is conducted by first analyzing the depiction of female characters
\end{abstract}


using the theory proposed by Ferguson. The analysis of the images of women is framed within the context of violence. The result of this analysis indicates that within the framework of Ferguson's Women's Images there are two types of images of women dominated in the two novels investigated namely: Women as the Submissive Wife and Man's Prey: the Sex Object. The Holy Woman also portray the images of depressed women abused by patriarchal structures.

Keywords: Shahraz, the image of women, violence, and patriarchal

\section{Pendahuluan \\ The Holy Woman, merupakan} novel pertama Qaisra Shahraz yang telah dipublikasikan pada tahun 2001. Qaisra Shahraz merupakan penulis novel perempuan berketurunan Pakistan lama tinggal di Inggris. Ia mendapatkan penghargaan Best Book of the Month versi Waterstones pada tahun 2001 untuk novel pertamanya ini. The Holy Woman/ "Perempuan Suci" (selanjutnya disebut THW) adalah novel pertamanya yang mendapatkan penghargaan best-seller. Ia juga dikenal sebagai penulis yang telah mendapatkan banyak penghargaan, di antaranya adalah Ian St. James Award pada tahun 1994, penghargaan untuk serial drama Dil Hee To Hai (The Heart Is It). Di samping itu, Shahraz merupakan salah satu nominasi penulis Asian Women of Achievement Awards pada tahun 2002 dan Muslim News Awards for Excellence pada tahun 2003. Ia menjadi jurnalis lepas di samping profesinya sebagai penulis dan konsultan pendidikan. Artikel-artikelnya telah dimuat di banyak majalah dan surat kabar, cerita-cerita pendeknya telah terbit di pelbagai belahan dunia.
Hal ini diakui oleh Athar (2011:39) dalam wawancaranya dengan Shahraz yang dimuat dalam jurnal International Solidarity, persoalanpersoalan yang diangkat dalam tulisannya bertema gambaran kehidupan perempuan Pakistan. Penulis perempuan asal Pakistan yang tinggal lama di UK ini menjadi salah satu penulis yang berpengaruh pada perkembangan kesusastraan dunia dan mampu memberikan inspirasi penulis perempuan lainnya. Tidak heran jika karya-karyanya mulai banyak diperbincangkan dalam wacana susastra feminin.

The Holy Woman (2002), Typhoon (2003), Rabbit English (1994), Writing Women - Twentieth Century Short Stories (1991), Dragon Fly in The Sun (1997), One Language Many Voices (2005-2006), Invitations To Literature (1990), Emerging India co-authored textbook for literature (2008), A Pairs of Jeans and Other Stories (2013), Revolt (2013), merupakan karyakarya yang ditulis Shahraz dalam beberapa bahasa di antaranya ditulis dalam bahasa Inggris, Jerman, Indonesia, Pakistan, India, dan Turki. Dari pembacaan awal terhadap beberapa karya Shahraz, saya mencatat 
beberapa hal yang menjadi kekhasan karya Shahraz ini. Yang pertama adalah konsistensi tema yang dibicarakan Shahraz dalam karya-karyanya yaitu membahas perempuan yang taat akan agama dan keluarga.

Shahraz menggunakan bahasa untuk mengungkapkan trauma kepedihan dan kesedihan. Sebagai tema besar, saya mengargumentasikan bahwa kepedihan dan kesakitan yang dihadirkan Shahraz tidak selalu menghadirkan tokoh perempuan yang terluka, melainkan sebuah perjuangan. Sebagai seorang pembaca saya menemukan berbagai alasan mengapa tokoh perempuan dalam novelnovelnya merasakan kepedihan dan kesakitan. Sebagai contoh, di dalam novel The Holy Woman, tokoh Zarri Bano melakukan perjuangan untuk mempertahankan keperawanannya demi harta yang dimiliki oleh keluarganya. Kemudian, narator menjelaskan bahwa Zarri Bano juga mengalami suatu hal untuk tidak melakukan pernikahan dengan siapa pun kecuali dengan Al-quran. Akibatnya, Zarri Bano bertekad untuk tidak menikah semasa hidupnya dan menjadi Shahzadi Ibadat, perempuan suci.

Penelitian ini diharapakan dapat menjawab pertanyaan-pertanyaan seputar citra perempuan. Penelitian ini juga diharapkan dapat menambah wawasan dalam ranah sastra, khususnya dalam wacana feminin.
Praktisnya penelitian ini dapat memberikan konsep penerapan citra perempuan dan isu femininitas dalam karya sastra.

\section{Kajian Teori}

\subsection{The Submissive Wife ; Perempuan Ideal}

Pandangan Ferguson (1977:17) dalam menanggapi The Submissive Wife, yaitu perempuan (istri atau anak perempuan) yang dapat memberikan kebahagiaan dan ketentraman untuk keluarganya. Dalam konteks ini perempuan yang menjadi istri atau anak perempuan dikategorikan sebagai perempuan ideal. Penggambaran stereotipe tentang perempuan "The Submissive Wife" membentuk perempuan untuk dapat patuh dan hormat terhadap suami/bapak, dapat tampil menawan, dapat mengurusi urusan rumah tangga yang berbau domestik dan mendidik anak. Hal ini senada dengan apa yang telah diutarakan.oleh Beauvoir (1956:120) melalui Kitab Perjanjian Lama maupun Perjanjian Baru:

For the man is not of the woman: but the woman of the man. And in another place: 'For the husband is the head of the wife; even as Christ is the head of the Church.... Therefore as the Church is subject unto Christ, so let the wives be to their own husbands in everything. 
Laki-laki bukan bagian dari perempuan; melainkan perempuan bagian dari laki-laki. Demikian juga halnya laki-laki bukan milik perempuan, tapi perempuan adalah milik laki-laki. Dan di bagian lain; Suami adalah pemimpin bagi istri, sebagaimana Kristus adalah pemimpin gereja. Oleh karenanya, sebagaimana gereja tunduk pada Yesus, istri harus tunduk pada suami dalam segala hal.

Di satu sisi, perempuan tidak dapat dilepaskan dari konstruksi budaya patriarki yang memberikan pengakuan atas femininitasnya. Di sisi lain, perempuan selalu mencari pengakuan atas femininintasnya. Tidak heran jika wacana tentang perempuan tidak akan pernah berujung. Konteks perempuan ideal ataupun yang diidealkan, sebagaimana dikutip oleh Prabasmoro (2003:49) dalam menanggapi pandangan Frakenberg (1997) tentang perempuan yang memiliki 'ras kulit putih', warna putih bukanlah warna melainkan semua warna.

Ke-putih-an adalah suatu konstruk atau identitas yang hampIr tidak mungkin dipisahkan dari dominasi rasial. Karena istilah ke-putihan-an, yang mengungkapkan gagasan bahwa ada kategori manusia yang diidentifikasi dan mengidentifikasi diri sebagai putih yang ditempatkan di dalam operasi ras dan rasisme yang terus menerus. Putih, karena itu, berkorespondensi dengan suatu tempat di dalam rasisme sebagai suatu sistem kategorisasi dan formasi subjek, sebagaimana istilah ras yang diuntungkan dan ras yang dominan menyebutkan suatu tempat tertentu di dalam kerangka rasisme sebagai suatu sistem dominasi.

Menjadi putih atau keputihan adalah wacana yang membudaya. Lebih lanjut Prabasmoro (2003:67) menegaskan bahwa kelas atas dengan penampilan "alamiah" dianggap berbudaya sedangkan mereka yang memakai rias wajah tebal dan berlebihan dianggap "tidak alamiah" karenanya menjadi "tidak berbudaya". Dapat diartikan bahwa yang alamiah itu adalah yang berbudaya.

\subsection{The Sex Object (Objek Seks)}

Kate Millet seorang feminis radikal dalam bukunya Sexual Politics (2000:127) menyatakan bahwa perbedaan jenis kelamin sekaligus permainan dalam berhubungan badan (coitus) memiliki nilainilai politis. Politik yang di maksud merupakan suatu kekuatan yang menguasai lainnya, jika dalam 
permasalahan ini adalah kekuasaan perempuan, maka politik tubuh yang dimaksud mengacu pada hal-hal yang disebut Millet sebagai ideological, biological, sociological, class dan economics and education.

No man ever yet entered life farther than the length of one navel-cord from the body of the woman who bore him. It is the woman who is the final standard of the race, from which there can be no departure for any distance for any length of time, in any direction: as her brain weakens, weakens the man's she bears; as her muscle softens, softens his; as she decays, decays the people. (Schreiner dalam Bristow:1997)

Tidak ada laki-laki yang pernah menjalani hidup lebih jauh dari pada panjangnya tali pusar dari tubuh seorang perempuan yang telah melahirkannya. Seorang perempuan yang menjadi pusat keberadaan ras, yang darinya bisa saja tidak terjadi kelahiran selama beberapa lama, ketika pemikirannya melemah maka melemah pula laki-laki yang dikandungnya, ketika perempuan merasa rileks maka begitu pula dengan laki-laki itu dan saat perempuan 'membusuk' maka orang-orang pun ikut membusuk.

Menurut Schreiner (1997:86) dalam menanggapi Bristow, laki-laki tidak pernah mampu mengenali tubuh perempuan, sekalipun dia yang melahirkannya. Laki-laki menganggap perempuan dalam kondisi yang pasif dan hanya mampu memberikan tanggapan jika diberi stimulasi terlebih dahulu. Padahal menurutnya, perempuan sangat berperan sebagai penerus generasi ketika pemikirannya melemah maka melemah pula laki-laki yang dikandungnya, ketika perempuan merasa rileks maka begitu pula dengan laki-laki itu. Saat perempuan membusuk maka orang-orang pun ikut membusuk. Secara biologis politik tubuh berbicara tentang maskulinitas dan femininitas serta perlakuan terhadap keduanya. Lebih lanjut Beauvoir (1956, 117-118) menjelaskan beberapa hal yang berkaitan dengan perempuan, bahwa ada beberapa hukum yang mendefinisikan perempuan sebagai objek.

Hukum manu mendefinisikan perempuan sebagai makhluk hina yang harus dibelenggu dalam perbudakan. Levicitus 
menyamakan perempuan tak ubahnya seperti hewan penghela yang dimiliki oleh seorang petani. Hukum Solon meniadakan hak-hak perempuan sementara undangundang Romawi menempatkan perempuan di bawah pengawasan dan menyatakannya 'dungu'. Hukum Canon mengganggap peremepuan sebagai 'pintu iblis'. Sementara kitab Suci umat Islam memperlakukan perempuan sebagai bahan cemoohan (Beauvoir: 117-118).

\subsection{Kekerasan Seksual dan Sosial Budaya}

Kekerasan adalah salah satu bentuk atau cara yang disengaja untuk menyakiti manusia (Danis, 2003 :239, Fagan, 1996 :237). Seseorang yang mengalami kekerasan akan berdampak cedera, baik itu secara fisik ataupun psikologis, fatal ataupun nonfatal. Kekerasan diindikasikan sebagai praktik dari kejahatan. Terkait dengan itu, Danis (2003:239) menyebutkan contoh kekerasan secara fisik yaitu melakukan kejahatan yang berbentuk penyiksaan dengan cara menganiaya seseorang hingga terjadi pembunuhan. Menurutnya para penyerang dan korban -hampir keseluruhan berjenis kelamin laki-laki. Alih-alih hal ini pun dapat berdampak pada kekerasan secara psikologis yang berujung dengan kekerasan seksual berbentuk pemerkosaan. Salah satu contoh kekerasan seksual dapat ditemukan di dalam rumah tangga.

Kekerasan dalam rumah tangga (domestic violence) selama periode 19451970 berdampak buruk terhadap perempuan baik itu secara fisik, psikologis, emosional, maupun praktik sosialnya untuk dapat berkesempatan hidup dan memiliki pilihan (Hague dan Wilson, $1996: 164$; York, $2009: 4)$. Perempuan pekerja dianggap sebagai perempuan yang tidak dapat terpenuhi kebutuhan perekonomian dalam rumah tangga. Terkait dengan itu, Hague dan Wilson (1996:160) menjelaskan bahwa kekerasan terhadap perempuan lebih sering terjadi di antara mereka yang miskin dan tidak berkelas. Ini menandakan bahwa adanya deskriminasi terhadap perempuan berdasarkan perbedaan ras, kelas dan budaya.

Hal ini dipertegas dengan pendapat Hague dan Wilson (1996:160) yang mendefinisikan kekerasan dalam rumahtangga sebagai salah satu kekerasan yang memanifestasikan dirinya melalui pengalaman berdasarkan perbedaan ras, kelas, dan budaya, meskipun ada sedikit keterangan bahwa lebih banyak kekerasan yang berlaku di beberapa kelompok sosial -budaya tertentu. Terkait dengan itu, York (2009:5) berpendapat bahwa kekerasan sosial budaya merupakan hasil dari budaya patriarki. 
Menurut York (2009:6), struktur patriarki menentukan status sosial suatu kelompok sebagai subordinat dari kelompok lain. Menurutnya, perempuan dianggap sebagai kelompok inferior. Dalam hal ini perempuan digambarkan sebagai objek seksual yang kehadirannya tidak lebih penting dari pada laki-laki. Struktur patriarki menghasilkan ketidaksetaraan dalam pernikahan, pengaturan keluarga, pendapatan, pemberian upah, agama, ekonomi, dan politik (York, 2009 :6). Sebagai contoh, perempuan sering menerima gaji/upah yang lebih rendah dan lebih sedikit untuk bekesempatan dalam sebuah pekerjaan dibandingkan laki-laki yang mengalami situasi serupa. Adanya kesenjangan dalam hal ini menyebabkan terjadinya kekerasan dalam sosial budaya terhadap perempuan.

\section{Hasil dan Pembahasan}

\subsection{Sepintas tentang Penulis}

Qaisra Shahraz adalah seorang penulis perempuan yang lahir di Pakistan dan tumbuh besar di UK. Semenjak umur 9 tahun, Ia telah tinggal bersama keluarganya di Mancheste. Ia tengah mendalami jurusan English and Classical Caivilization di Universitas Manchester dan meneruskan pendidikannya di Universitas Salford untuk mengambil konsentrasi English and European Literature and Scripwriting for Televesion and Radio. Ia tengah banyak mengikuti acara workshop dan training dalam mengembangkan "Qualitiy in Education" di Pakistan dan India sebagai pendiri dari British Council. Sebagai seorang penulis, ia telah memiliki aspirasi untuk menulis semenjak umur belasan tahun. Ia berfokus dalam meneliti isu tentang perempuan, terutama perempuan muslim yang telah terpengaruh oleh pemikiran budaya Barat.

Karya pertama yang diterbitkan adalah A Pair of Jeans pada tahun 1988 bercerita tentang isu pakaian, mode perempuan, identitas dan budaya. Karya-karyanya banyak tersebar di pelbagai belahan dunia seperi di UK, Jerman, Holland, India, Indonesia, Pakistan, dan Turki. Adapun karyakarya lainnya yang tersebar adalah berbentuk short stories dan novel, yaitu A Pair Of Jeans, Holding Out, Black And Priceless, What Big Eyes You Have Got, Acclaim Magazine, No Limits, Rabbits English, Dragon Fly In The Sun, Pakistani Writing In English, The Elopement, Invitations To Literature (1990), Writing Women - Twentieth Century Short Stories (1991), The Holy Woman (Perempuan Suci, 2001), Typhoon (2003), the World Changed - Writing by Pakistani Women Writers (2005), dan Neither Night nor Day - 13 Stories by Women Writers from Pakistan (2007). The Holy Woman adalah karya Shahraz yang berbeda dengan novel atau karya Shahraz lainnya. The Holy Woman ini merupakan karya Shahraz yang 
mendapatkan penghargaan Best Book of the Month 2001 versi Waterstones.

\section{Dari pemaparan tersebut, diketahui bahwa Qaisra Shahraz merupakan pengarang dan penulis kritik sastra yang sangat produktif. Beberapa karyanya juga mendapatkan penghargaan. Oleh karena itu, telah banyak apresiasi yang diberikan terhadap karya-karyanya.}

\subsection{Ringkasan cerita The Holy Woman}

The Holy Woman adalah novel karya Qaisra Shahraz yang menggambarkan tokoh perempuan, seorang putri bangsawan dari Lahore, Pakistan. Berawal dari keluarga Habib Khan dan Shahzada yang memiliki tiga orang anak yaitu Zarri Bano, Jafar, dan Ruby. Jafar berkedudukan sebagai anak laki-laki tunggal memiliki peranan penting dalam keluarga, yaitu sebagai penerus tahta dan kekayaan keluarga. Zarri Bano sebagai anak perempuan tertua adalah seorang perempuan modern dan glamor. Zarri Bano adalah perempuan modern yang berubah menjadi seorang perempuan muslim dan sederhana. Zarri Bano yang banyak diinginkan oleh para laki-laki ini berkali-kali menolak lamaran bangsawan terkemuka di tanah kelahirannya, Pakistan, seperti Ali dan Khawar juga para tamu laki-laki lainnya yang datang dari segala penjuru.

Pada suatu saat dalam pesta rakyat, Zarri Bano bertemu dengan seorang lelaki yang bernama Sikander. Sikander adalah seorang pengusaha kaya yang sangat dicintai oleh Zarri Bano dan sebaliknya, sehingga akhirnya Sikander berniat untuk melamar Zarri Bano. Namun, pernyataan itu tidak mudah diterima oleh sang Ayah, Habib Khan, begitu saja. Ada beberapa proses yang harus dilewati oleh Sikander untuk dapat memiliki Zarri Bano, yaitu ia harus siap dan berani untuk berhadapan dengan seorang Habib Khan, seorang tuan tanah dari kalangan sosial tinggi. Ia menginginkan pendamping yang sebanding dengan putrinya dalam segala hal terutama dalam kehidupan sosial dan pendidikan. Hal ini dapat diatasi oleh Sikander karena Sikander adalah seorang putra dari seorang Chaudarani Bilqis yang berasal dari Karachi. Ketika mereka berada di Karachi. Pertemuan mereka semakin erat sehingga mereka memastikan agar segera mendapat restu dari kedua orangtua untuk melangsungkan pernikahan.

Sepulang dari Karachi, Zarri Bano mendapatkan kabar bahwa adiknya, Jafar, telah tewas karena terjadi kecelakaan. Kematian Ja'far adalah kematian pula bagi Zarri Bano untuk dapat mewujudkan impiannya, yaitu menikah dengan laki-laki impiannya, Sikander. Tanggung jawab yang telah diberikan kepada Ja'far, kini beralih tangan menjadi tanggung jawab Zarri Bano yang secara tidak langsung 
sebagai anak tertua Zarri Bano harus meneruskan dan menjaga harta yang dimiliki oleh Habib Khan. Harapan Zarri Bano menjadi putus untuk menikah dengan Sikander karena Habib Khan menetapkan Zarri Bano menjadi seorang perempuan suci, Shahzadi Ibadat, yaitu menjadi seorang perempuan suci yang senantiasa mengagungkan agama dengan cara menikahi Al-quran sebagai pengganti dari kematian Jafar. Dengan perasaan terpaksa, Zarri Bano harus meninggalkan laki-laki yang dicintainya demi mempertahankan tahta dan kekayaan yang dimiliki oleh Ayahnya. Kematian anak laki-laki dalam keluarganya berarti keharusan bagi Zarri Bano sebagai anak perempuan tertua untuk menggantikan peran Jafar sebagai pewaris utama tahta dan kekayaan dari Ayahnya. Ketika Zarri Bano memilih untuk melepaskan Sikander demi menuruti perintah ayahnya yang memegang kuat tradisi, Ia menukarkan cintanya demi adat istiadat keluarganya yang salah. Sebuah pilihan pilu untuk setiap perempuan. Pergulatan batin Zarri Bano dimulai ketika Ia ingin hidup sebagai perempuan normal yang menikah dan memiliki sebuah keluarga. Zarri Bano adalah perempuan modern yang di kalangan banyak orang bahkan dilihat hampir tidak pernah memakai tutup kepala

\footnotetext{
${ }^{1}$ Perempuan suci, zahidah; perempuan yang mengabdikan seluruh hidupnya untuk beribadah
}

dengan benar. Tapi, Zarri Bano tidak kuasa untuk melawan keinginan ayahnya semata karena rasa hormatnya. Zarri Bano menjadi Perempuan Suci. Tubuhnya tertutup burqa. Biasanya burqa menutupi seluruh tubuh dan hanya menyisakan celah di bagian mata (cadar). Namun, pengarang mengartikan burqa yang dipakai Zarri Bano sebagai tutup kepala yang masih menampakkan wajah pemakainya, seperti jilbab yang sangat lebar (Shahraz, 2012:707). Zarri Bano yang menjadi seorang Shahzadi Ibadat ${ }^{1}$ diharuskan memakai burqa sebagai pembatas dirinya dengan dunia luar. Rasa keterpaksaan itu dirasakannya pada masa awal ketika ia mengenakan burqa. Namun, seiring dengan berjalan waktu akhirnya ia pun terbiasa untuk mengenakan baju muslim hitam itu.

Pada suatu saat, Zarri Bano merasa terpukul karena diketahuinya bahwa Sikander akan melamar adik tercintanya, Ruby. Hal ini menekan batinnya karena ternyata laki-laki yang selama ini didambakannya, bersanding dengan sang adik. Ini merupakan suatu tantangan hidup yang harus dijalaninya, yaitu melawan perasaan lamanya yang pernah tumbuh untuk Sikander. Kebiasaan memakai burqa telah menjadikan ia menjadi seorang Shahzadi Ibadat yang sejati sehingga 2012:708). 
tidak ada keinginan yang terbesit untuk dapat menikah dengan laki-laki manapun. Kehidupannya hanya ia sandarkan untuk agama dan beribadah semata. Zarri Bano berada dalam realitas seorang perempuan yang hidup di tengah kungkungan tradisi yang dibangun oleh lakilaki/ Ayahnya, Habib Khan.

\subsection{Penggambaran Tokoh Citra Perempuan dalam Novel The Holy Woman}

Analisis novel berjudul The Holy Woman karya Qaisra Shahraz berikut ini didasarkan pada analisis penggambaran tokoh citra perempuan Mary Ann Ferguson (1977).

\section{Citra Perempuan Ideal dan Objek Seks}

Dalam menganalisis novel ini akan dipaparkan imajinasi pengarang yang ditampilkan lewat tokoh dan tokoh perempuan Zarri Bano dalam novel The Holy Woman ini. Namun, untuk penelitiannya sendiri saya akan meleburnya.

Ideologi menurut Peck dan Coyle (1993:146) adalah kepercayaan atau suatu konsep cara berpikir untuk menghasilkan ide atau citra untuk memahami dunia. Ideologi dalam hal ini adalah proses dimana pengarang dapat menciptakan karya-karyanya

\footnotetext{
${ }^{2}$ Mengandung unsur-unsur pengatur yang harus dipatuhi sehingga hubngan antarmanusia ditentukan atau paling sedikit dipengaruhi oleh tata
}

atau biasa kita sebut dengan latar belakang kehidupan pengarang. Imajinasi pengarang yang dapat menentukan nasib pengarang memposisikan pengarang di tengah masyarakat yang menjadi pembaca karya sastra. Oleh karenanya, suatu masyarakat tertentu sebagai pembaca yang menghidupkan karya sastra menjadi faktor kesuksesan bagi pengarang. Novel The Holy Woman yang telah memenangkan hadiah penghargaan dari Waterstones pada tahun 2001 ini menjadi salahsatu sasaran bagi para pembacanya untuk dapat dianalisis.

Kecenderungan dalam menilai suatu asumsi dalam masyarakat tertentu ditentukan oleh nilai normatif ${ }^{2}$ yang dimiliki oleh suatu masyarakat tertentu sehingga unsur nilai normatif dalam karya sastra diperlukan untuk muncul ke permukaan karena hal ini akan menjadi penentu bagaimana masyarakat tertentu dapat berkembang. Adalah Zarri Bano, putri dari Habib Khan, yang menggantungkan hidupnya hanya untuk menjadi Shahzadi Ibadat. Dalam konteks ini, konsep menjadi seorang Shahzadi Ibadat adalah sesuatu hal dimana ia harus melakukan katarsis. yaitu proses pensucian dirinya melalui beberapa tahap, diantaranya ia harus menikahi Al-quran sebagai pedoman

kemasyarakatan tersebut. (lihat Hardjana, 1994:70 dalam memaparkan Sosiologi Sastra dalam kritik sastra). 
hidupnya juga ia harus bertekad untuk tidak menikah. Hal ini terkesan menjadi paradoks, yaitu menjadikan Al-quran sebagai pedoman hidup adalah benar namun tidak menikah selama hidupnya adalah ketentuan yang harus dipikirkan secara matang.

My beautiful Zarri Bano was destined for this fate. Her brother's death sealed her future as a Shahzadi Ibadat. This is what has always happened when only sons died in people of our class; the inheretance then was passed on the next female member (Shahraz, 2001:42).

Zarri Banoku yang cantik sudah di takdirkan atas nasibnya ini. Kematian adiknya menetapkan masa depannya sebagai Shahzadi Ibadat. Inilah yang selalu terjadi saat para putra tunggal meninggal dunia di kalangan kita. Warisan akan jatuh pada anggota keluarga perempuan berikutnya - kau tahu itu (Shahraz, 2001:42).

Hal lain yang dapat dilihat adalah burqa yang menjadi pilihan selanjutnya setelah ia dijadikan sebagai perempuan suci. Peranan burqa sebagai benda pembatas eksistensi dirinya dan dunia luar telah membuat ia lebih mendalami tentang bagaimana ajaran agamanya harus diterapkan dalam kehidupan kesehariannya. Istilah penyucian diri atau katarsis yang digunakan oleh Zari Bano merupakan salah satu upayanya dalam membentuk ideologinya menjadi seorang Shahzadi Ibadat (perempuan suci). Katarsis yang merujuk pada upaya pembersihan atau penyucian diri, pembaruan rohani dan pelepasan diri dari ketegangan. Hal ini telah dilakukan oleh Zarri Bano sebagai seorang perempuan suci yang telah menjanjikan hidupnya untuk menikah dengan Al-quran. Boal (1985:106) menyatakan bahwa katarsis merupakan penyucian yang diproses oleh para penonton dalam sebuah pentasan sandiwara. Proses penyucian diri menjadi suci dinilai berbeda dalam beberapa agama, diantaranya dalam agama Kristen istilah ini digunakan sebagai pembaharuan mental seseorang dengan proses dirinya menjadi suci dan terjaga. Mereka mengistilahkan perempuan yang tidak menikah seumur hidupnya dengan istilah biarawati, sedangkan dalam agama Islam disebutkan sebagai perempuan suci (sufi). Penyucian diri yang membawa pembaruan rohani dalam tubuh Zarri Bano ini, telah melepaskan dirinya dari ketegangannya dengan Habib Khan atas kematian Jafar. Kelegaan emosional dirasakannya setelah Zarri Bano dinikahkan dengan Al-quran sebagai kepercayaan sepanjang hidupnya.

Her brain was suddenly attacked by the image of herself 
enveloped in long black cloak. 'How can I wear a burqa? She moaned to herself. I will never get used to it, it not me. I who have a natural instinct for galmour and fashion, I will ne smotheed alive behind it.' (Shahraz, 2001:86)

"Bagaimana aku mampu mengenakan burqa?" ratapnya pada dirinya sendiri. "Aku tidak akan pernah terbiasa mengenakannya. Bukan aku. Aku yang memiliki naluri alamiah terhadap kemewahan dan mode ini akan tercekik hidup-hidup di balik jubah itu (Shahraz, 2001:86).

Konsep menjadi seorang Shahzadi Ibadat yang terjadi pada tokoh perempuan fiktif Zarri Bano ini menggambarkan kehidupan yang dililit oleh tradisi kebudayaan tertentu, yaitu kebudayaan yang menempatkan dirinya untuk dapat menduduki posisi laki-laki yang dikabarkan meninggal sebagai pengganti dan penerus warisan dalam tradisi keluarganya. Dengan demikian, kasus ini menjadikan Zarri Bano untuk dapat mengikuti tradisi keluarganya. Meskipun demikian, Zarri Bano tidak membenarkan gejala sosial yang terjadi dalam tradisi keluarganya untuk menjadi perempuan suci. Sebaliknya, Zarri Bano menentang kenyataan bahwa menjadi perempuan suci adalah sesuatu yang tidak normal baginya. Kehidupan yang normal baginya adalah menjadi perempuan yang dapat menikah dan dapat memberikan keturunan.

I want to be a normal woman, Father, and live a normal life! I want to get married. I am not a very religious person, as you know. I am a twentieth-century, modern, educated woman. I am not living in the Mughal perioda pawn in a game of male chess. Don't you see, Father, I have hardly ever prayed in my life, not opened the Holy Quran on a regular basis. How can I become a Holy Woman? I am not suited to that role. Father, I want -' Shahraz, 2001: 54-55)

"Aku ingin menjadi perempuan normal Ayah dan hidup normal! Aku ingin menikah. Aku bukanlah orang saleh, seperti yang Ayah tahu. Aku seorang perempuan modern yang terpelajar dari abad kedua puluh. Aku tidak hidup di zaman Mughal - seorang pion dalam permainan catur kaum lelaki. Tidakkah kau lihat, Ayah, aku jarang sekali shalat dalam hidupku, tidak juga rajin membuka Al-Quran dan menggunakannya sebagai pedoman. Bagaimana mungkin kau kemudian menjadi seorang Perempuan Suci? Aku tidak cocok untuk peranan itu. Aku ingin _-' (Shahraz, 2001: 54-55) 
Dalam faktor lain, hal yang mendukung tejadinya satu gejala sosial lain adalah teciptanya satu tradisi dimana yang menjadi vokal adalah suara maskulinitas. Adalah laki-laki yang memiliki kekuasaan penuh atas keputusan tertentu. Suara perempuan tidak diperkenankan untuk bertindak atas sesuatu karena perempuan dalam konteks ini tidak memiliki hak untuk meyuarakan pendapatnya.

As a woman, she was of no consequence- her opinion counted for nothing. A law unt themselves, men's words were commands, and they were born to be obeyed. They possessed a succesful knack of reasoning, and make everything sound so plausible. In the face of their thinly disguied tyranny one could never hope to win or to challenge them. They were always steps ahead of you and very adepts as that. (Shahraz, 2001:47)

Sebagai seorang perempuan, dia tidak memiliki kekuatan apa pun pendapatnya tidak berarti. Hukum berlaku di antara mereka; kata-kata kaum lelaki adalah perintah, dan mereka dilahirkan untuk di patuhi. Mereka memiliki kemampuan khusus dalam hal memberi dalih sehingga segalanya terdengar begitu meyakinkan. Di hadapan kezaliman mereka yang dengan tebal tersamarkan itu, perempuan tidak akan pernah bisa berharap menang atau menantang mereka. Mereka selalu selangkah di muka dan sangat cekatan dalam hal itu. (Shahraz, 2001:47)

Menjadi seorang Perempuan Suci atau Shahzadi Ibadat merupakan sesuatu hal yang tidak lazim dalam konsep agama Islam. Namun tradisi ini telah berhasil memasung hak manusiawi perempuan di Pakistan, tepatnya di Sindu selama turun temurun. Tradisi Perempuan suci yang salah kaprah mengatasnamakan agama Islam untuk melarang perempuan menikah. Sang perempuan suci dalam tradisi ini disebutkan hanya boleh menikah dengan Alquran. Lalu mengabdikan hidup hanya untuk menjadi ulama yang menyebarkan agama Islam. Sebuah tradisi turun temurun yang mengatasnamakan Alquran dan Islam namun jelas-jelas bertentangan dengan keduanya. Pengarang berdarah Pakistan, Qaisra Shahraz yang telah banyak menuai penghargaan sastra tingkat internasional menceritakan bagaimana tradisi itu menjadi luka bagi perempuan.

Menurut Gramsci (Ratna, 2010:183), ada tiga cara untuk membentuk gagasan, yaitu: bahasa, pendapat umum (common sense) dan 
folklor. Ketiga komponen ini merupakan komponen yang berpengaruh dalam memerankan ideologi yang bersumber sebagai sentral. Bahasa merupakan konsep utama dalam berkomunikasi, pendapat umum merupakan tempat berkumpulnya ideologi yang bersifat setara dan berlawanan, sedangkan folklor merupakan kepercayaan rakyat atau cerita rakyat yang diwariskan secara turun temurun juga berperan dalam memerankan hegemoni yang berfungsi sebagai pengikat ideologi masyarakat tanpa ada rasa keterpaksaan. Bahasa, pendapat umum, dan folklor merupakan tiga elemen penentu seseorang dalam memerankan status sosialnya. Berikut adalah kutipan yang menjelaskan hegemoni terhadap stereotipe gender:

You have probably herad about our tradition of a Holy Woman and heiress of clan. Well, when the only male heir dies, in out clan, the inheritance, and especially the land, goes to the next female heir. The condition is that she stays and never leaves her paternal home. In effect, she can never marry. To make this more legitimate, our forefathers concocted the notion of a Holy Woman, a Shahzadi Ibadat. It is a measure for men like my father of ensuring that the land stays in the family. (Shahraz, 2001: 115).
"Anda mungkin pernah mendengar tentang tradisi kami mengenai sorang Perempuan Suci dan ahli waris kelaurga kami. Saat satusatunya ahli waris laki-laki meninggal dunia, di keluarga besar kami, warisannya, dan khususnya tanah-tanahnya, akan diturunkan kepada ahli waris perempuan berikutnya. Perempuan itu diisyaratkan tidak akan pernah meninggalkan rumah ayahnya. Akibatnya, dia tidak bisa menikah. Untuk mengesahkan ini nenek moyang kami menciptakan status Perempuan Suci, seorang Shahzadi Ibadat. Itu adalah sebuah ukuran bagi laki-laki seperti ayahku untuk memastikan tanahnya tetap menjadi milik keluarga."

Status Zarri Bano dalam keluarga berkaitan dengan stereotipe gender ini telah mengikat tubuh Zarri Bano dengan tradisi keluarga yang telah dibentuk secara turun temurun, yaitu menjadi pengganti ahli waris demi mempertahankan tanah keluarganya, jika saat satu-satunya ahli waris laki-laki meninggal dunia. Kematian Jafar, adik Zarri Bano, yang seharusnya menduduki tahta dan warisan keluarga menjadi satu keharusan bagi Zarri Bano untuk tidak melakukan pernikahan semasa hidupnya. Keberadaan tubuh Zarri Bano sebagai anak perempuan tertua ditetapkan menjadi seorang 
perempuan suci yang semasa hidupnya senantiasa menjadi seorang perawan. Hal ini telah dibentuk oleh tradisi yang dibentuk oleh nenek moyangnya secara turun-temurun. Hegemoni terhadap gender telah menggantikan posisi Jafar sebagai anak laki-laki, dimana Zarri Bano melakukan pemindahan status menjadi pewaris tunggal setelah kematian adiknya. Peranan Zarri Bano yang beralih dari feminin ke maskulin ini dapat dikategorikan sebagai stereotip gender berdasarkan status sosial dalam keluarga.

Sexism adalah prasangka dan diskriminasi terhadap individu karena jenis kelamin seseorang. Seseorang yang mengatakan bahwa perempuan tidak bisa menjadi seorang pemimpin dalam keluarga sama artinya orang itu termasuk orang yang sexism. Mengutip bacaan Mulvey yang merujuk pada Freud (Gamble, 2004:53) tentang bagaimana pembentukan awal subjek bawah sadar perempuan memungkinkan identifikasi lintas jenis kelamin. Adalah Zarri Bano, putri dari Habib Khan, yang menggantungkan hidupnya hanya untuk menjadi Shahzadi Ibadat. Dalam konteks ini, konsep menjadi seorang Shahzadi Ibadat adalah sesuatu hal dimana ia harus melakukan lintas jenis kelamin dari feminin menjadi maskulin. Artinya, sebagai seorang perempuan yang menjadi pewaris tahta keluarga ini telah menjadikan Zarri Bano sebagai seseorang yang memiliki karakter maskulin. Untuk memperoleh karakter itu ia harus melakukan beberapa proses, yaitu proses pensucian dirinya melalui beberapa tahap, diantaranya ia harus menikahi Al-quran sebagai pedoman hidupnya juga ia harus bertekad untuk tidak menikah. Dengan melakukan proses pensucian ini yang akhirnya membawa Zarri Bano melakukan lintas kelamin memiliki karakter maskulin.

My beautiful Zarri Bano was destined for this fate. Her brother's death sealed her future as a Shahzadi Ibadat. This is what has always happened when only sons died in people of our class; the inheretance then was passed on the next female member (Shahraz, 2001:42)

Zarri Banoku yang cantik sudah di takdirkan atas nasibnya ini. Kematian adiknya menetapkan masa depannya sebagai Shahzadi Ibadat. Inilah yang selalu terjadi saat para putra tunggal meninggal dunia di kalangan kita. Warisan akan jatuh pada anggota keluarga perempuan berikutnya- .

Persoalan tentang ras selalu diperbincangkan dalam wacana umum. Diskriminasi merujuk kepada suatu pelayanan yang tidak adil terhadap individu tertentu, di mana layanan ini dibuat berdasarkan 
karakteristik yang diwakili oleh individu tersebut. Diskriminasi merupakan suatu kejadian yang selalu dijumpai dalam masyarakat manusia, ini disebabkan karena kecenderungan manusia untuk membeda-bedakan manusia lain. Ketika seseorang tidak diperlakukan secara tidak adil baik itu dalam wacana suku, antargolongan, kelamin, kondisi fisik, ras, agama, politik, ataupun kepercayaan tertentu maka hal ini termasuk tindakan diskriminasi. Wacana diskriminasi ini merupakan salah satu penyebab dari stereotip gender yang menyebabkan ketidakadilan terjadi pada seseorang. Wacana diskriminasi yang terkait dengan stereotip gender ini telihat pada diskriminasi kondisi fisik Zarri Bano yang menjadi perempuan tertua. Diskriminasi ini memiliki kaitan dengan ranah politik, bahwa dengan dimunculkannya wacana tentang diskriminasi maka secara tidak langsung sang Ayah, Habib Khan, tidak ingin merasa kehilangan putrinya setelah kematian putranya. Sang Ayah memposisikan Zarri Bano sebagai pengganti dari putranya.

I want to be a normal woman, Father, and live a normal life! I want to get married. I am not a very religious person, as you know. I am a twentieth-century, modern, educated woman. I am not living in the Mughal perioda pawn in a game of male chess.
Don't you see, Father, I have hardly ever prayed in my life, not opened the Holy Quran on a regular basis. How can I become a Holy Woman? I am not suited to that role. Father, I want _-' Shahraz, 2001: 54-55)

"Aku ingin menjadi perempuan normal Ayah dan hidup normal! Aku ingin menikah. Aku bukanlah orang saleh, seperti yang Ayah tahu. Aku seorang perempuan modern yang terpelajar dari abad kedua puluh. Aku tidak hidup di zaman Mughal - seorang pion dalam permainan catur kaum lelaki. Tidakkah kau lihat, Ayah, aku jarang sekali shalat dalam hidupku, tidak juga rajin membuka Al-Quran dan menggunakannya sebagai pedoman. Bagaimana mungkin kau kemudian menjadi seorang Perempuan Suci? Aku tidak cocok untuk peranan itu."

Prabasmoro

(2010:81) beranggapan bahwa, "penis dikonstruksi sebagai senjata, dan hanya laki-laki yang punya senjata untuk "menembak". Tubuh laki-laki lebih dianggap lebih compact karena penis berfungsi untuk mengeluarkan urine dan juga untuk menembakkan sprema. Penis dijadikan representasi diri." Kedudukan yang dimiliki oleh Habib Khan sebagai Ayah adalah salah satu representasi yang ditampilkan oleh Shahraz sebagai seorang laki-laki yang 
memiliki kuasa atas kehendaknya dengan penis yang dimilikinya. Hal ini dapat dilihat ketika Habib dengan secara paksa memaksa Zarri Bano untuk melepaskan tubuhnya menjadi seseorang yang terhindar dari dunia luar dengan membatasi dirinya untuk tidak bergaul dengan sembarang orang (menjadikannya sebagai perempuan yang suci, yang tidak pernah disentuh keperawanannya oleh siapapun). Prabasmoro (2007:42) menyatakan bahwa, "tubuh bagi aliran feminisme radikal adalah persoalan mendasar yang menunjukkan bahwa perempuan berbeda dari laki-laki, dan bahwa perbedaan itu bukan hanya berlaku paralel tetapi lebih bersifat superior." Posisi Zarri Bano sebagai anak dan juga perempuan tidak dapat bebas menentukkan kehidupannya secara bebas. Ia dibalut oleh budaya patriarki yang telah ditanamkan oleh sang Ayah melalui konsep perbedaan kelamin secara tidak langsung, yaitu menjadi seorang anak yang turut dan pasrah atas kehendak yang diinginkan oleh sang Ayah.

The woman he created by killing me. Did you not know that men are true creators in our culture, Mothers? They mould our lives and destinies according to their whims and desires. The irony of all ironies, for which I can never forgive myself, is that it has happened to me - a feminist, a defender of women's rights. (Shahzada, 2001:56)

"Sang Perempuan Suci. Perempuan yang diciptakan Ayah unyuk membunuhku. Tidakkah kau tahu bahwa para lelaki adalah pencipta sesungguhnya dalam kebudayaan kita, Ibu? Mereka mencetak kehidupan dan takdir kita sesuai dengan hasrat dan nafsu mereka. Yang paling ironis dari segala ironis, karena aku tidak amapu memaafkan diriku sendiri karenannya, adalah bahwa ini terjadi pada diriku - seseorang yang membela hak kaum perempuan."

Konteks lain yang berkaitan adalah konsep burqa' yang digunakan oleh Zarri Bano telah mengubah dan menolak gagasan ia sebagai seorang feminis modern, yaitu dengan melepaskan konsep perempuan yang mewah dan bermode dari kehidupannya. Melepaskan kehidupannya yang mewah dan bermode membuat ia harus membunuh diri secara tidak langsung dengan melarikan dirinya masuk ke dalam dunia asing baru yang harus ditempatinya. Jauh sebelum kematian Jafar, Zarri Bano adalah seorang perempuan terpelajar dan modern. Pandangan eksistensialis terhadap kehidupan manusia dalam hal ini menunjukan perhatian terhadap pengalaman badani yang dialami oleh 
Zarri Bano tanpa atribusi maknawi. Artinya, Zarri Bano secara maknawi tidak mengetahui secara pasti tentang konsep tubuhnya yang telah dibentuk oleh budaya patriarki dan dibangun sang Ayah demi mempertahankan tubuh Ayahnya yang secara tidak langsung digantikan oleh Jafar, dan sebagai representasi dari pengalaman badani Zarri Bano, akhirnya Zarri Bano harus dapat menggantikan tubuh Jafar sebagai pengganti ahli waris dan tahta Habib Khan.

'How can I wear a burqa? She moaned to herself. I will never get used to it, it not me. I who have a natural instinct for galmour and fashion, I will ne smotheed alive behind it.' (Shahraz, 2001:86)

"Bagaimana aku mampu mengenakan burqa?" ratapnya pada dirinya sendiri. "Aku tidak akan pernah terbiasa mengenakannya. Bukan aku. Aku yang memiliki naluri alamiah terhadap kemewahan dan mode ini akan tercekik hidup-hidup di balik jubah itu.

Menurut Hollows (2010:204), berpakaian demi kesuksesan adalah bagian dari wacana yang lebih luas pada tahun 1980-an yang memproduksi identitas feminin baru, "wanita karir". Cara berpakaian yang menunjukkan kekuasaan memberi para perempuan pekerja profesional memiliki alasan untuk mereka sebagai wanita karir. Dalam hal ini burqa' yang dikenakan oleh Zarri Bano merupakan gambaran dari jabatan yang kini disandangnya, yaitu menjadi perempuan suci. Menjadi perempuan suci yang berarti tubuh yang terhindar dari duniawi telah menjadikan ia seorang perempuan sufi, yaitu perempuan yang hanya menyerahkan tubuhnya untuk beribadah semata terhadap Tuhan dan Agamanya. Burqa sebagai benda pembatas eksistensi dirinya dan dunia luar telah membuat ia lebih mendalami tentang bagaimana ajaran agamanya harus diterapkan dalam kehidupan kesehariannya. Istilah penyucian diri atau katarsis yang digunakan oleh Zari Bano merupakan salah satu upayanya dalam membentuk ideologinya menjadi seorang Shahzadi Ibadat (perempuan suci).

My sister, it will seem very strange to wear this veil at first, but you'll soon get used to it. Female modety, and the general veiling of women is part of faith and culture. As you know. Therefore, this is no different garment than that worn by any Muslims women, say in Iran, for example. They have been wearing these since the revolutio- ordinary women, who ear it outside for their modesty. Here in Pakistan we have always had the burqa. It's just that you 
have necer worn it before and it has gone out of fashion somewhat, lately. (Shahraz, 2001:96)

"Saudariku, akan sangat aneh mengenakan jilbab ini pada awalnya, tetapi kau akan segera terbiasa nanti. Menutupi aurat perempuan adalah bagian dari keyakinan dan budaya kita, sebagaimana yang kau ketahui. Karena itu, tidak ada bedanya gaya berbusana yang digunakan seluruh Muslimah, katakan saja di Iran, misalnya. Mereka sudah mengenakan pakaian seperti ini sejak revolusi mereka- perempuan biasa, yang mnggunakannya di luar rumah untuk menutupi aurat mereka. Disini, di Pakistan, kita selalu mengenakan burqa."

\section{Penutup}

Berdasarkan analisis di atas, representasi femininitas yang memanfaatkan peneliti an hegemoni terhadap stereotip gender ini dapat dikategorikan berdasarkan pada ras, bangsa, sex, status sosial, dan agama. Dominasi femininitas yang memanfaatkan hegemoni terhadap stereotip gender atas ras akan berpengaruh pada politik. Pembacaan hegemoni terhadap gender atas bangsa akan berpengaruh pada ranah kebudayaan. Hegemoni terhadap stereotip atas seks dan status sosial akan berpengaruh pada kondisi fisik seseorang. Hegemoni terhadap stereotip atas agama akan berpengaruh kepada kepercayaan seseorang dengan Tuhan. 


\section{Daftar Pustaka:}

Athar Khalid, etc. 2011. International Solidarity: Celebrating Literary Tradition and Ingenuity. Pakistan: English Writer.

Beauvoir, Simone de. 1956. The Second Sex. London: Jonathan Cape Thirty Bedford Square.

Boal, Augusto. 1985. Theatre of The Oppressed. Theatre Communications Group:New York

Butler, Judith. 1990. Subjects of sex/gender/desire in "Gender Trouble:feminism and the subversion of identity" (Performatives Acts and Gender Constitution: An Essay in Phenomology and Feminist Theory). Australia:John Hopkins University Press, p270-282.

Ferguson, Mary Ann. 1977. Images of Woman. Boston: University of Massachusetts.

Gamble, Sarah. 2004. Feminsim and Postfeminism. London and New York: The Routledge Companion.

Hollows, Joanne. 2010. Feminisme, Feminitas dan Budaya Populer. Yogyakarta: Jalasutra.

Millet, Kate. 1977. Sexual Politics. London:Virago.

Peck, John daCoyle, Martin. 1993. Literary Terms and Critisism. Macmillan :London.

Plahakova, Alena.2007. Implicit theories of Masculinity and Femininity. Faculty of Medicine: Pro-Quest Research Library. Prabasmoro, Aquarini P. 2007. Kajian Budaya Feminis Tubuh, Sastra, dan Budaya Pop. Yogyakarta: Jalasutra.

Shahraz, Qaisra. 2001. The Holy Woman. London: BlackAmber Books Limited.

Strinati, Dominic. 2004. Popular Culture. Yogyakarta: Bentang. 